late friend. It is of course impossible to supply the place of the naturalist whose collections I shall do the best to describe, for with him has perished much knowledge of the habits and distribution of the animals, and although this want can be partially atoned for by the copious notes he has left behind, much unfortunately can never be replaced. . . . There is always more difficulty in procuring specimens of Mammalia than in collecting terrestrial animals belonging to most of the other classes of vertebrata and invertebrata, and this is especially the case with the larger forms. It is consequently not to be expected that the species represented will be more than a portion of those inhabiting the country. Still the collection is rich in some respects, and especially in kinds of rodents, and it adds largely to our knowledge of the fauna of Western Tibet and Eastern Turkistan. The larger mammals, indeed, were originally batter represent:d, but after Dr. Stoliczka's death many specimens appear to have been removed from the collection. Such at least was the case with the ruminants. In a private letter which Dr. Stoliczka wrote to me, he told me he had sent twenty-two skins of wild sheep from Kashgar. Of these only eleven - seven males and four femalesare now forthcoming, and not one of these has fine horns. There is not a single specimen of Ozis poli from the Pamir, the original locality, although I have reason to believe that Dr. Stoliczka brought away one head at least. Lastly, there are skeletons of wild sheep and ibex in the collection of which the heads have disappecared. It is highly probable that other specimens besides those of Ovis poli have been similarly made over to private individuals. The value of the collection has been seriously diminished by its being broken up, and the finest specimens distributed, before it had been examined," \&c.

(True extract.) H. H. GODWIN-AUSTEN,

Superintendent Topographical Survey of India

\section{Glands of the Cherry Laurel}

In NATURe (vol. viii., p. 245) Mr. Thiselton Dyer, in answer to a correspondent, says that he knows of no explanation of the purpose or origin of the nectariferous glands on the back of the leaf of the cherry laurel. Mr. Darwin ("Origin of Species," sixth edition, p. 73) says : "Certain plants excrete sweet juice, sixtic eding something injurious from the sap; this is effected, for instance, by glands at the base of the stipules in some Leguminosw, and at the backs of the leaves of the common laurel. This juice, though small in quantity, is greedily sought by insects; but their visits do not in any way greedily sought by insects ; but the be considered very complex modifications of cellular tissue. They exist on all parts of plants, and contain a great variety of secretions. Mr. Darwin and others have shown that they perform the varied functions of secreting nectar to attract insects to flowers, of secreting odorous matter for the same purpose, of absorhing ammonia from rain-water and the products of decomposed or digested animal or vegetable matter, and of secreting acids capable of digesting solids. The existence of free acids in the plant would be injurious to it, so that their excretion would be beneficial to it apart from any digestive function which they may in some cases perform. The glands of the laurel are so far unspecialised that they are by no means constant in number or size. As their attracting insects is of no service to the plant, the nectar must be said to be excreted ; but, being what Sachs has termed (p. 629) a "secondary product of metastasis," it should be looked upon rather as a physiologically accidental excretion than as positively injurious, as a substance which, having ceased to take part in the processes of awth, has not acquired an indirect function as has the nectar of flowers. To account for the position of the glands it may be suggested that, as in other evergreens, the leaves of the laurel are "reservoirs of reserve material" in which metastasis, in. cluding the separation of the "formative materials" from the "secondary products," mainly takes place (Sachs, p. 627).

\section{8, Westbury Road, Harrow Road, W.} G. S. BOULGER

\section{Saw-fish inhabiting Fresh Water}

I AM not aware if a curious fact connected with the lake near Manila has been noticed by any traveller.

The Laguna de Baij is a large sheet of water some ninety miles in circumterence, divided by an island and two peninsulas, from in circumierence, it is often spoken of as the "lakes." This lagoon receives the waters of the small rivers of the provinces of the Laguna and Morong, and its only outlet is the river Pasig, which flows into the bay between the military city and suburbs of Manila. The volume of water discharged by the Pasig is augmented by that of another river which joins the main stream some eight or nine miles from Manila, and during gales in the S. W. monsoon, which prevent the free egress of the water, the Pasig overflows and covers the flat land round Manila.

The water of the lake is quite fresh, and after settling, perfectly potable. At certain times the waters of the lake of Baij possess an urticating property which makes bathing very disagreeable from the irritation they produce. The natives (who account for everything in some way or other) attribute this to the Pistia, a plant which is so abundant as to fill up small bays and form floating islands of considerable size. Great quantities of this plant are carried down the river into the bay, and are seen sometimes a long way out at sea, killed and yellow from the effect of the salt water. Sections of the leaves are beautiful microscopic objects. The lake is separated from the Bay of Manila by a few miles of very flat land, and there can be little doubt that before this barrier was thrown up it formed part of, or at least communicated with, the bay. One proof that the waters were once salt is the existence of a bank of fossil oysters at the point of Julu-julu, some twenty miles from the outlet by the river. When this barrier was raised the waters of the lake became gradually fresh from the infux of those of a number of small rivers which drain the surrounding provinces, the only outlet for which (as before mentioned) is tise river Pasig.

The peculiarity to which I have alluded is the existence of a species of small shark and numbers of Saw-fish (Pristis) in the perfectly fresh water of the lake. They are seldom or never met with in the river, but there is a fishery in the lagoon in which numbers of the latter are taken. The flesh is eaten, the livers give a good deal of oil, and the snouts of the larger specimens make very formidable weapons, which the natives use and which are at times sent down to Manila as curiosities. These saw-insh, now living in perfectly fresh water, have no doubt become gradually accustomed to the change, as has been the case with the marine species of Crustacea discovered by Prof. Lóven in the fresh water lakes of Sweden. *

I am unable to describe the sharks, which I think from the account given me are a small species of dog-fish, quite harmless. Very different, however, are a larger kind inhabiting the brackish water of the lake of Bombon, in which is situated the active volcano of Taal (south-east of the great lake, about twenty or twenty-five miles distant by road). This kind of shark is feared by the natives, who avoid bathing at points which they frequent. Manila

W. W. WOOD

\section{Observations on Fish}

IN May last the writer dug a tank within the premises at Garden Reach. About the end of July it was stocked with young fish of several kinds, among others a species of carp, called by the natives "Katlah," which abounds in the turbid waters of the Hooghly, within the range of the tides. The fry varied from half an inch to an inch in length, some even smaller. The "Kutlah" does not breed in fresh water, but attains an extraordinary size in a wonderlully short time in ponds. So very rapid has been the increase of the fish in question, that the fact seems worthy of chronicle in the pages of NATURE. On Sept. 22 , the tank was swept with nets to catch one or two fish of the pike species that had been introduced accidentally with the others, and attained a size that rendered them dangerous to the fry of other kinds. In the net several dozens of the "carp" referred to were taken; one of the largest weighed $14 \mathrm{oz}$, and measured II inches from the end of the upper lip to the tip of the tail, $I_{\frac{3}{4}}^{3}$ inches thick behind the shoulder, and $3 \frac{1}{2}$ inches in breadth; the others were only one or two ounces lighter.

The tank (pond) in which these fish throve so marvellously is only 65 feet long by $5^{8}$ feet broad, and $x 3$ feet deep. The natives, many of whom live within the compound, wash their rice and other food in the water, preparatory to cooking, furnishing the fish with a large amount of food. As the writer saw the tank dug and the fish put in, there cannot be a doubt about their increase in the short space of three months from small fry barely an incit lung, to fair-sized fish II to I4 Oz. in weight, measuring from to to II inches. ROBERT U. S. MITCHELL

\section{Misti and its Cloud}

IN NATURE, vol. xii. p. $487, \mathrm{Mr}$. Stevenson gives an interesting example of the genesis of clouds, due to hills of about * See Nature, vol. i. p, 454 . 